\title{
The trophic action of growth hormone, insulin- like growth factor-I, and insulin on human duodenal mucosa cultured in vitro
}

\author{
E E Wheeler, D N Challacombe
}

\begin{abstract}
Background-Experimental evidence suggests that hormones may regulate small intestinal adaptation after surgical resection.

Aims-To characterise the effect of recombinant human growth hormone (GH), insulin-like growth factor-I (IGF-I) and insulin on crypt epithelial cell proliferation in the human duodenal mucosa cultured in vitro.
\end{abstract}

Patients-Thirty nine adults had endoscopic duodenal biopsy specimens taken, which were histologically normal and pair matched specimens from each patient acted as their own control.

Methods-Paired biopsy specimens from patients were cultured in vitro, with or without the addition of GH (0.004 IU/ml), IGF-I (400 $\mathrm{ng} / \mathrm{ml})$ or insulin (50 $\mu \mathrm{g} / \mathrm{ml})$, alone or in combination. After 22 hours, vincristine sulphate was added to the cultures and three hours later specimens were removed and fixed, and DNA stained by the Feulgen method. Intestinal crypts were microdissected and crypt epithelial cell proliferation determined by estimating mean numbers of accumulated metaphase arrests/crypt present in tests and controls between 22-25 hours of culture.

Results-The addition of GH, IGF-I, and insulin, alone or in combination, significantly increased crypt epithelial cell proliferation in test explants compared with controls. IGF-I was most potent and its trophic effect was modified by insulin. Conclusions-GH, IGF-I, and insulin are involved in the regulation of crypt cell proliferation in the human small intestine in vitro and possibly in vivo.

Keywords: growth hormone, insulin-like growth factor-I, trophic action, small intestinal mucosa, organ culture.

Somerset Children's

Research Unit,

Taunton and Somerset

Hospital, Taunton,

Somerset

E E Wheeler

D N Challacombe

Correspondence to:

Dr D N Challacombe,

Somerset Children's

Research Unit, Taunton and

Somerset Hospital,

Musgrove Park, Taunton,

TA1 5DA

Accepted for publication

29 July 1996 factor-I (IGF-I) on the human small intestine until recently, when both hormones were shown to stimulate crypt epithelial cell proliferation (CECP) in duodenal explants cultured in vitro. $^{12} \mathrm{GH}$ has a mitogenic effect on crypt epithelial cells in the duodenum of hypophysectomised rats ${ }^{3}$ and when given alone causes hypertrophy of the rat gastrointestinal
(Gut 1997; 40: 57-60)

tract to supranormal levels. ${ }^{4} \mathrm{GH}$ increases body weight, distal ileal weight, and mucosal height in rats undergoing $75 \%$ small bowel resection ${ }^{5}$ as well as growth and differentiation in transplanted rat intestine in early neonatal life. ${ }^{6} \mathrm{GH}$ receptors are present in crypt and villus epithelial cells of rats, ${ }^{7}$ suggesting a direct cellular effect of $\mathrm{GH}$ on small intestinal growth. GH stimulates the synthesis of IGF-I in the liver and other tissues, ${ }^{8}$ which mediates GH dependent cellular proliferation. IGF-I receptors have also been immunolocalised in the gastrointestinal tract of rats ${ }^{9} 10$ and IGF-I given subcutaneously to dexamethasone treated rats increases the total weight of all regions of the bowe ${ }^{11}$ and improves mucosal adaptation after small bowel resection. ${ }^{12}$ Insulin receptors are also present in the intestinal epithelium of rats $^{1314}$ and insulin stimulates epithelial cell proliferation in the suckling mouse intestinal mucosa. ${ }^{15}$

These findings suggest that GH, IGF-I, and insulin, alone or in combination, are involved in the regulation of CECP or epithelial cell differentiation, or both, in the human small intestinal mucosa in vivo. In this study, an organ culture technique ${ }^{1}$ has been used to investigate the action and interaction of recombinant GH, IGF-I, and insulin, on CECP in explants of the human duodenal mucosa cultured in vitro in an insulin free medium, using a stathmokinetic technique with crypt microdissection. ${ }^{1617}$

\section{Methods}

Patients

Mucosal biopsy specimens obtained by fibreoptic endoscopy (Olympus GIF 1T) from the third or fourth part of the duodenum of 39 adults (21 men; median age 63, range 31-92) with upper gastrointestinal disorders were studied, with ethics committee approval. All specimens were expelled from biopsy forceps into cold Leibowitz L-15 medium, transported to the laboratory, and flattened serosal surface downwards, using aseptic techniques. Specimens for routine histopathology were fixed in $10 \%$ formol saline and the remainder bisected to provide six or seven explants of approximately $2 \mathrm{~mm}^{2}$ for culture in vitro.

\section{Organ culture}

The organ culture technique ${ }^{1}$ maintained the morphological integrity and proliferative viability of duodenal explants in vitro for at least 
48 hours, without added insulin. Biopsy specimens were placed mucosal surface upward on $1 \mathrm{~cm} \times 1 \mathrm{~cm}$ gelatin sponge squares (Gelfoam, Upjohn, Kalamazoo, USA), attached to the base of a $60 \mathrm{~mm}$ sterile plastic culture dish (Falcon). Paired biopsy specimens from each patient were their own controls and were cultured in basic medium with added rhGH (Genotropin, Pharmacia), rhIGF-I (Pharmacia) or rh insulin (Sigma), alone or in combination. Test and control specimens were cultured under identical conditions in separate culture dishes. The basic culture medium was both serum and insulin free and contained 9.65 ml CMRL 1066 medium supplemented with $0.2 \mathrm{ml} \mathrm{L}$-glutamine $(200 \mathrm{mM}), 0.1 \mathrm{ml}$ penicillin/streptomycin (10000 $\mathrm{U}$ of each), $0.05 \mathrm{ml}$ Fungizone, $10 \mathrm{mg}$ glucose, $0.2 \mathrm{mg}$ ascorbic acid, and $10 \mu \mathrm{g}$ hydrocortisone hemisuccinate. The medium was sterilised by a $0 \cdot 2$ $\mu$ Acrodisc filter (Gelman Sciences). Culture

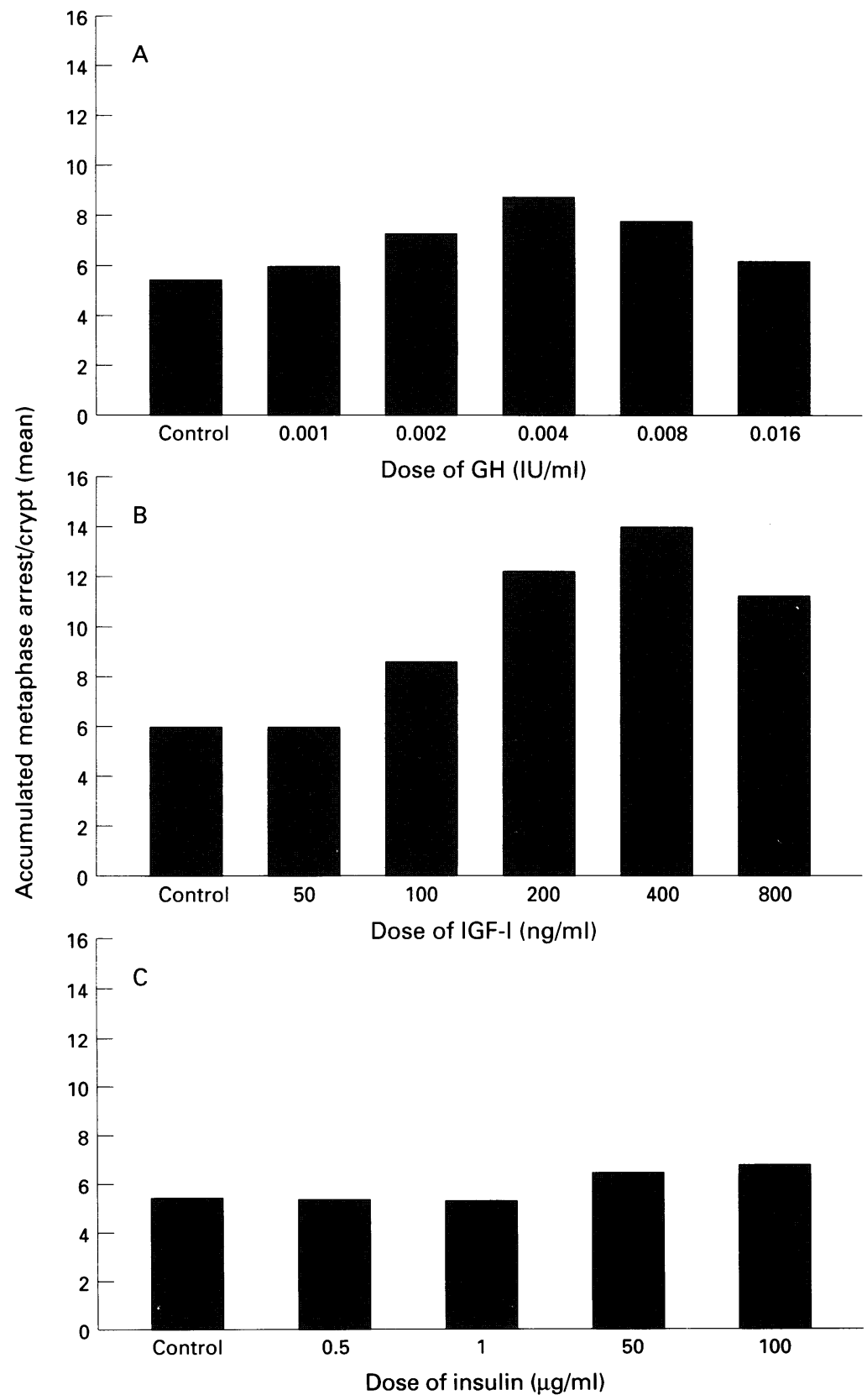

Figure 1: Dose/response studies of (A) GH, (B) IGF-I, and (C) insulin, on CECP in the duodenal mucosa. dishes were placed in a controlled atmosphere chamber (Bellco Glass Inc), sealed, and placed on a rocking apparatus in a $37^{\circ} \mathrm{C}$ incubator and rocked at $3 \mathrm{rpm}$ in an atmosphere of $95 \%$ oxygen and $5 \%$ carbon dioxide.

\section{Crypt epithelial cell proliferation (CECP)}

Control and test explants were maintained in organ culture for 22 hours when $0.7 \mu \mathrm{g} / \mathrm{ml}$ of vincristine sulphate (Oncovin, Lilly) was added to start the stathmokinetic experiment. Explants were removed after three hours, fixed in Carnoy's fluid for four hours, and stored in $70 \%$ alcohol before rehydrating and staining DNA by the Feulgen method. Intestinal crypts were separated by microdissection in $45 \%$ acetic acid, squashed under a coverslip, and viewed by light microscopy. The mean number of metaphase arrests accumulating between 22-25 hours in 15 crypts from different parts of each specimen was determined and expressed the CECP. Statistical analysis of the difference between means in test and control explants was obtained using a paired Student's $t$ test.

Dose/response studies

Dose/response studies were performed by adding rhGH (Genotropin, Pharmacia) $0.001-0.016 \mathrm{IU} / \mathrm{ml}$ of culture medium, rhIGF-I (Pharmacia) 50-800 ng/ml, and $\mathrm{rh}$ insulin (Sigma) $0.5-100 \mu \mathrm{g} / \mathrm{ml}$ respectively, to duodenal explants from three patients at the beginning of organ culture and estimating the CECP at 25 hours. From the results (Fig 1), $0.004 \mathrm{IU} / \mathrm{ml}$ of $\mathrm{GH}, 400 \mathrm{ng} / \mathrm{ml}$ of IGF-I, and $50 \mu \mathrm{g} / \mathrm{ml}$ of insulin were the doses selected for further studies.

\section{Results}

Histological appearances of the duodenal mucosa were initially normal by light microscopy and showed good preservation of villous architecture and epithelial cells for up to 25 hours. The addition of GH, IGF-I or insulin to the culture medium, alone or in combination, significantly increased the mean numbers of metaphase arrests/crypt accumulating between $22-25$ hours in test specimens compared with controls $(p<0 \cdot 001)$. The CECP in test specimens cultured with IGF-I alone, GH/IGF-I, or GH/insulin, was significantly higher than specimens cultured with insulin alone, $\mathrm{GH}$ alone, $\mathrm{IGF} /$ insulin, and $\mathrm{GH} /$ IGF-I/insulin $(p<0 \cdot 001)$. (Table and Fig 2$)$.

\section{Discussion}

In this study, insulin alone stimulated CECP in the duodenal mucosa and may have acted via insulin receptors or by cross reacting with IGF-I receptors. ${ }^{18-20}$ The dose of insulin (50 $\mu \mathrm{g} / \mathrm{ml}$ ) was the same as that used in Trowell's classic organ culture medium ${ }^{21}$ and was considerably higher than normal plasma insulin values in humans $(0.42 \mu \mathrm{g} / \mathrm{ml})$. High concentrations of insulin $(1-10 \mu \mathrm{g} / \mathrm{ml})$ probably cross 
Mean number of metaphase arrests/crypt - tests v pair matched controls

\begin{tabular}{|c|c|c|c|c|}
\hline & Patients & Mean & $S E M$ & $\mathrm{t}$ Test \\
\hline Tests+insulin & 8 & $7 \cdot 3$ & $0 \cdot 44$ & \\
\hline Controls & 8 & $5 \cdot 3$ & 0.32 & $\mathrm{p}<0.001$ \\
\hline Tests+GH & 8 & $7 \cdot 6$ & 0.43 & \\
\hline Controls & 8 & $5 \cdot 8$ & $0 \cdot 23$ & $\mathrm{p}<0.002$ \\
\hline Tests+IGF-I & 8 & $12 \cdot 9$ & $0 \cdot 72$ & \\
\hline Controls & 8 & $5 \cdot 8$ & $0 \cdot 18$ & $\mathrm{p}<0.001$ \\
\hline Tests $+\mathrm{GH}+$ insulin & 9 & $12 \cdot 0$ & $0 \cdot 40$ & \\
\hline Controls & 9 & $5 \cdot 8$ & $0 \cdot 40$ & $\mathrm{p}<0.001$ \\
\hline Tests+GH+IGF-I & 8 & $12 \cdot 9$ & $0 \cdot 44$ & \\
\hline Controls & 8 & $5 \cdot 8$ & $0 \cdot 23$ & $\mathrm{p}<0.001$ \\
\hline Tests+IGF-I+insulin & 8 & $8 \cdot 3$ & 0.59 & \\
\hline Controls & 8 & $5 \cdot 8$ & $0 \cdot 40$ & $\mathrm{p}<0.001$ \\
\hline Tests $+\mathrm{GH}+\mathrm{IGF}-\mathrm{I}+$ insulin & 9 & $7 \cdot 6$ & 0.43 & \\
\hline Controls & 9 & $5 \cdot 8$ & $0 \cdot 40$ & $\mathrm{p}<0.001$ \\
\hline
\end{tabular}

react with IGF-I receptors and concentrations of up to $6.5 \mu \mathrm{g}$ insulin $/ \mathrm{ml}$ have been shown to induce mitogenesis in cultured human skin fibroblasts via IGF-I receptors. ${ }^{20}$ Insulin may induce a diphasic proliferative response on cultured skin fibroblasts, acting via insulin receptors at low concentrations and via IGF-I receptors at high concentrations. ${ }^{22}$ In studies on cultured small intestinal crypt cell lines (IEC-6), increased cell proliferation did not occur until high insulin concentrations were present $(1-10 \mu \mathrm{g} / \mathrm{ml})$, suggesting an action via IGF-I rather than insulin receptors. ${ }^{19}$ The need to use relatively high doses of hormones and other agents is a commonly observed phenomenon in organ culture experiments, as they reach cells by diffusion, in the absence of a blood supply. ${ }^{15}$ However even after making allowances for this phenomenon, the present findings showed that higher than normal tissue concentrations of insulin stimulated intestinal CECP, probably via IGF-I receptors, which may be of pathophysiological significance.

The dose of GH used to stimulate CECP $(0.004 \mathrm{IU} / \mathrm{ml} ; 1.6 \mu \mathrm{g} / \mathrm{ml})^{1}$ was higher than plasma concentrations in normal adults $(<0 \cdot 2-3 \cdot 1 \mathrm{ng} / \mathrm{ml})$. GH also has a trophic action on duodenal epithelial cells in experimental animals ${ }^{3}$ and overcomes gut hypoplasia induced by hypophysectomy in rats. ${ }^{4}$ Specific $\mathrm{GH}$ binding proteins and receptors are present in small intestinal columnar cells of adult rats

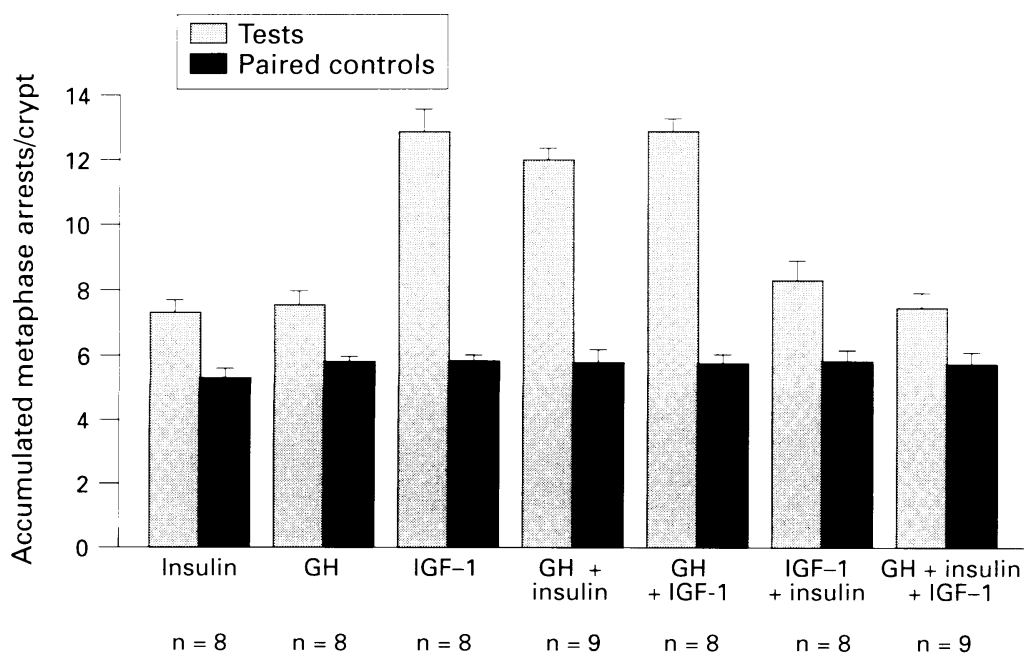

Figure 2: Mean number of metaphase arrests/crypt at 25 hours of culture after addition of insulin, $G H$, and IGF-I to the culture medium. and $\mathrm{GH}$ could have a direct cellular action on CECP in the human intestinal mucosa. As IGF-I is also expressed in the small intestinal epithelium, GH could have stimulated CECP in this study by inducing local synthesis of IGF-I, which then acted in an autocrine/ paracrine manner.

The potent action of IGF-I on CECP probably occurred via IGF-I receptors and the dose used $(400 \mathrm{ng} / \mathrm{ml})$ approximated normal plasma values in adults $(315+/-27 \mathrm{ng} / \mathrm{ml})$, which is mostly protein bound. IGF-I is mitogenic for many types of cultured cells in vitro, accelerating somatic growth in experimental animals and inducing the selective growth of tissues such as thymus, kidney, and spleen. ${ }^{23}$ Free IGF-I is a potent trophic factor in the normal small intestinal mucosa of rats. In humans, circulating levels of free IGF-I have a half life of about 20 minutes, ${ }^{24}$ increasing to 13-20 hours when bound to carrier proteins (IGFBPs). ${ }^{25} 26$ Free IGF-I in exocrine secretions (saliva, gastric, juice, jejunal chyme, pancreatic juice, and bile) could also influence growth in the human gastrointestinal epithelium in vivo, and the concentration in the gut lumen is approximately $180 \mathrm{ng} / \mathrm{ml}$ of jejunal chyme. ${ }^{27}$

$\mathrm{GH} /$ insulin stimulated CECP and the result was higher than either hormone alone, suggesting a cumulative trophic response as described above. Furthermore as hepatic $\mathrm{GH}$ receptors in diabetic rats are insulin dependent, ${ }^{28}$ high doses of insulin could have influenced the maintenance of $\mathrm{GH}$ receptors available for ligand binding in this study. The effect of $\mathrm{GH} /$ IGF-I on CECP was similar to IGF-I alone and greater than $\mathrm{GH}$ alone, suggesting an action mediated solely by IGF-I. The effect of IGF-I/insulin on CECP was lower than IGF-I alone, but slightly higher than insulin alone, suggesting that a high insulin dose may have decreased the trophic action of IGF-I by competing for IGF-I receptors. A combination of GH, IGF-I, and insulin stimulated CECP, but the result was significantly lower than that of IGF-I alone, of GH/insulin and of GH/IGFI $(p<0 \cdot 001)$. These findings suggest that a high dose of insulin could have saturated IGF-I receptors and modified the action of IGF-I on CECP, but partial suppression of the trophic action of $\mathrm{GH} /$ insulin cannot be explained.

By studying cultured explants of the human duodenal mucosa in vitro, isolated from biological control of the intact organism, it has been possible to investigate actions of hormones regulating CECP more directly than would have been ethically possible in vivo. With the exception of hydrocortisone, the culture medium was free of known hormones and other growth factors influencing CECP. Hydrocortisone enhances the preservation of human small intestinal explants in long term organ cultures and its presence maintains a relatively higher steady state of epithelial cell proliferation in vitro (EEW, personal observation). Any influence it may have had on the action of GH, IGF-I, and insulin in short-term organ cultures is unknown.

The results of this study have shown that insulin, GH, and IGF-I had a significant 
trophic effect on CECP in vitro. Growth control mechanisms responsive to GH, IGF-I or insulin in the human small intestinal mucosa will need further investigation, particularly to determine whether GH initiates an IGF-I autocrine/paracrine loop. Synthesis of IGF-I close to its locus of action in the bowel may have greater physiological significance than secretions of hormones from endocrine glands. ${ }^{8}$ Small bowel growth is increased in transgenic mice overexpressing bovine $\mathrm{GH}^{29}$ and subcutaneous administration of IGF-I improves mucosal structure and absorptive function after small bowel transplantation in rats. ${ }^{30}$ IGF-I and GH could be involved in the regulation of crypt cell proliferation in the human small intestinal mucosa in vivo and contribute to the adaptive changes occurring in the small intestine after surgical resection.

We are grateful for the assistance of Dr Michael Barry and Dr Sterling Pugh and for the support of Pharmacia.

This study was presented as a poster at the 19th International

This sudy Endocrinology and Metabolism, Prague, 21-22 April, 1995.

1 Challacombe DN, Wheeler EE. The trophic action of human growth hormone on the human duodenal mucosa cultured in vitro. $f$ Pediatr Gastroenterol Nutr 1995; 21 50-3.

2 Challacombe DN, Wheeler EE. Safety of milk from cows treated with bovine somatotrophin. Lancet 1994; 344: $815-6$.

3 Leblond CP, Carriere RM. The effect of growth hormone and thyroxine on the mitotic rate of the intestinal mucosa and thyroxine on the mitotic rate of the in

4 Scow RO, Hagan SN. Effect of testosterone propionate and growth hormone on growth and chemical composition of muscle and other tissues in hypophysectomised male rats Endocrinology 1965; 77: 852-8.

5 Shulman DI, Shih Hu C, Duckett G, Lavallee-Grey M Effects of short-term growth hormone therapy in rats undergoing $75 \%$ small intestinal resection. $₹$ Pediat Gastroenterol Nutr 1992; 14: 3-11.

6 Cooke PS, Yonemura CU, Russell SM, Nicoll CS. Growth and differentiation of fetal rat intestine transplants: dependence on insulin and growth hormone. Biol Neonate 1986; 49: 211-8.

7 Lobie PE, Breipohl W, Waters MJ. Growth hormone receptor expression in the rat gastrointestinal tract. receptor expression in the rat

8 Van Wyk JJ, Casella SJ, Hynes M, Lund PK. Indirect actions of growth hormone. In: Underwood LE, ed. Human growth hormone: progress and challenges. New York: Marcel Dekker, 1988: 25-61.

9 Hansson HA, Nilsson A, Isgaard J, Billig M, Isaksson OGP Skottner A, et al. Immunohistochemical localization of insulin like growth factor-I in the adult rat. Histochemistry 1988; 89: 403-10.

10 Ryan J, Costigan DC. Determination of the histological distribution of insulin-like growth factor-I receptors in rat gut. Gut 1993; 34: 1693-7.
11 Read LC, Tomas FM, Howarth GS, Martin AA, Edson KJ, Gillespie CM, et al. Insulin-like growth factor-I and its $\mathrm{N}$-terminal modified analogues induce marked gut growth in dexamethasone treated rats. $\mathcal{F}$ Endocrinol 1992; 133: 421-31.

12 Vanderhoof JA, McCusker RH, Clarke R, Mohamadpour H, Blackwood DJ, Harty RF, et al. Truncated and native insulin-like growth factor-I enhance mucosal adaptation after jejunoileal bypass. Gastroenterology 1992; 102: 1949-56.

13 Forgue-Lafitte ME, Marescot MR, Cahmblier MC, Rosselin G. Evidence for the presence of insulin binding Rosselin G. Evidence for the presence of insulin binding
sites in isolated rat intestinal epithelial cells. Diabetologia sites in isolated rat

14 Fernandez-Moreno MD, Serrano-Rios M, Prieto JC. Identification of insulin receptors in epithelial cells from duodenum, jejunum, ileum, caecum, colon and rectum in the rat. Diabetes Metab 1987; 13: 135-9.

15 Arsenault $\mathrm{P}$, Menard D. Insulin influences the maturation and proliferation of suckling mouse intestinal mucosa in serum free culture. Biol Neonate 1984; 46: 229-36.

16 Goodlad RA, Wright NA. Quantitative studies on epithelial cell replacement in the gut. In: Titchem DA, ed. Techniques in the life sciences. Digestive phyiology. Vol P2. Ireland: Elselvier Biomedical, 1982: 212/1-23.

17 Challacombe DN, Wheeler EE. Trophic action of epidermal growth factor on human duodenal mucosa dermal growth factor on human

18 Froesch ER, Zapf J. Insulin-like growth factors and insulin: comparative aspects. Diabetologia 1985; 28: 485-93.

19 Conteas CN, McMorrow B, Luk GD. Modulation of epidermal growth factor-induced cell proliferation and receptor binding by insulin in cultured epithelial cells. Biochem Biophys Res Commun 1989; 161: 414-9.

20 Van Wyk JJ, Graves DC, Casella SJ, Jacobs S. Evidence from monoclonal antibody studies that insulin stimulates deoxyribonucleic acid synthesis through the type 1 somatomedin receptor. 7 Clin Endocrinol Metab 1985; 61: 639-43.

21 Trowell OA. The culture of mature organs in a synthetic medium. Expt Cell Res 1959; 16: 118-47.

22 Conover CA, Hintz RL, Rosenfeld RG. Comparative effects of somatomedin $\mathrm{C}$ and insulin on the metabolism and of somatomedin $\mathrm{C}$ and insulin on the metabolism and growth of cult 122 : $133-41$.

23 Froesch ER, Guler HP, Schmidt C, Zapf J. Metabolic and growth effects of IGF-I in vitro and in vivo. Devl Endocrinol 1990; 67: 141-53.

24 Guler H-P, Zapf Z, Froesch ER. Short-term metabolic effects of recombinant human insulin-like growth factor-I in healthy adults. $N$ Engl $f$ Med $1987 ; 317: 137-40$.

25 Blethen SL, Daughaday WM, Weldon VV. Kinetics of the somatomedin C/insulin-like growth factor-I response to exogenous growth factor $(\mathrm{GH})$ in $\mathrm{GH}$-deficient children. 7 Clin Endocrinol Metab 1982; 54: 986-90.

26 Hodgkinson SC, Davis SR, Burleigh BD, Henderson HV, Gluckman PD. Metabolic clearance rate of insulin-like growth factor-I in fed and starved sheep. $¥$ Endocrinol 1987; 115: 233-40.

27 Chaurasia OP, Marcuard SP, Seidel ER. Insulin-like growth factor-I in human exocrine secretions. Regul Pept 1994; 50: $113-9$.

28 Baxter RC, Turtle JR. Regulation of hepatic growth hormone receptors by insulin. Biochem Biophys Res Commun 1978; 84: 350-7.

29 Ulshen MH, Dowling RH, Fuller CR, Zimmermann EM, Lund PK. Enhanced growth of small bowel in transgenic mice overexpressing bovine growth hormone. Gastroenterology 1993; 104: 973-80.

30 Zhang W, Frankel W, Adamson WT, Roth JA, Manten MP, Bain A, et al. Insulin-like growth factor-I improves mucosal structure and function in transplanted rat small intestine. Transplantation 1995; 59: 755-61. 